- was on duty as one of the headquarters guards with Gen. Sherman on many of his campaigns, and was one of the honorary pall bearers at the General's funeral. Mr. Kephart has been a highly esteemed citizen of Webster City for many years, is a past commander of the local post of the Grand Army of the Republic, and is now a member of the local Board of Education. As soldier and citizen his record is a most honorable one.

Yours very traly,

G. W. Croshey.

\title{
AN EXPLANATION.
}

Editor of The Annaxs: The last number of The Annals of Iowa contains a communication criticising the descriptive and historical sketch of Boone county contained in the Iowa State Atlas, published last year.

The sketches of the various counties, prepared for the State Atlas, were mostly compiled from old county histories published twenty to forty years. ago, and from their early date supposed to be accurate. Before publication these compilations were submitted to parties residing within the counties for review, criticism and correction. In many cases they were sent to the county superintendent as one being most likely to take un interest in the matter; in some cases to the county auditor, and in others to. some private citizen.

In regard to Boone county, the editor's record shows that the sketch of that county was compiled from one written over thirty years ago, and was. reviewed by a resident of Boone county and returned with his approval.

Very respectfully,

The Iowa Publishing Company.

Davenport, Iowa; Nov. 12, 1905 .

\section{VALUABLE BOUND VOLUMES OF EARLY NEWSPAPERS.}

James G. Edwards was a foremost newspaper editor, first in the State. of Illinois at Jacksonville, and afterwards in the Territory and State of Iowa at Fort Madison and Burlington. Four bound volumes of the newspapers he edited have been presented by Mrs. Louisa Prince Love, of Camden, N.J., to the public library of Burlington. They are invaluable to historical students of the period of twenty-one years which they cover. Mrs. Love is a niece of Mr. Edwards' wife, and was brought up in his family, as was her sister, Ellen, who was married to Major General John M. Corse (Annals, ii, 2). Mr. James Love died last year. He was an honored and beloved citizen of Burlington, a bookseller, a warm personal friend of Henry George, author of "Progress and Poverty."

The volumes of newspapers are:

1. The Western Observer, Jacksonville, Ill., No. 3 to No. 49, from May 3, 1830, to May 14, 1831:

2. The Fort Madison Patriot, No. 1 to No. 13, from March 24, 1838, to. July $25,1838$.

The Burlington Patriot. Specimen number. Dec. 13, 1838.

The Iowa Patriot, Burlingtion, No. 1 to No. 18, from June 6 to August: $29,1839$.

The Hawk-Eye and Iowa Patriot, from Sept 5, 1839, to May 27, 1841.

3. The Burlington Hawk-Eye, from May 29, 1845, to Feb. 8, 1848 .

4. The Burlington Hawk-Eye, from March 22, 1849, to June 26, 1851. w. 8.. 
Copyright of Annals of Iowa is the property of State of Iowa, by \& through the State Historical Society of Iowa and its content may not be copied or emailed to multiple sites or posted to a listserv without the copyright holder's express written permission. However, users may print, download, or email articles for individual use. 